
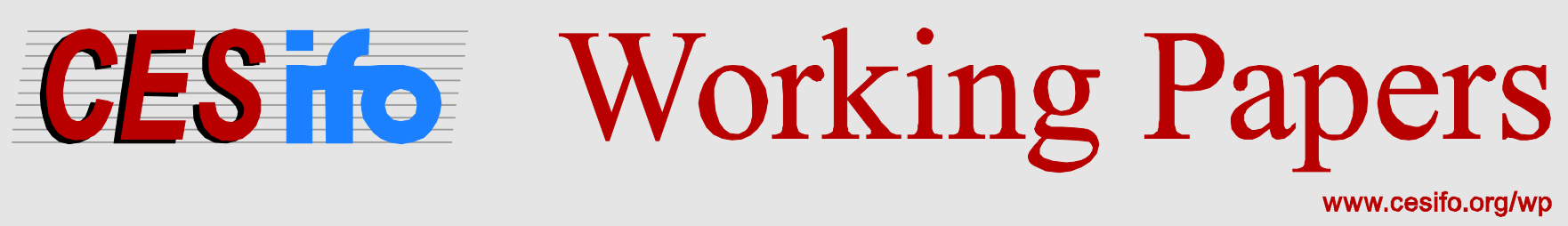

\title{
Political Capitalism: The Interaction between Income Inequality, Economic Freedom and Democracy
}

\author{
Tim Krieger \\ Daniel Meierrieks
}

CESIFO WORKING PAPER NO. 5681

CATEgory 2: Public CHOICE

DECEMBER 2015
An electronic version of the paper may be downloaded
- from the SSRN website:
- from the RePEc website:
- from the CESifo website:
wWw.SSRN.com
www.RePEc.org
www.CESifo-group.org/wp




\title{
Political Capitalism: The Interaction between Income Inequality, Economic Freedom and Democracy
}

\begin{abstract}
In this contribution we study the relationship between income inequality and economic freedom for a panel of 100 countries for the 1971-2010 period. From a panel causality study we find that income inequality has a negative causal effect on economic freedom, while causation does not run in the opposite direction. We argue that the negative effect of inequality on economic liberty is due to the elite's political power stemming from its disproportionate control over a country's economic resources. The elite uses this power to curtail economic freedom to defend its economic interests by discouraging innovation, competition and protecting its rents. Running a series of dynamic panel estimations, we show that the negative effect of income inequality on economic freedom is robust to different sets of controls and estimation techniques. Finally, we show that the dynamics of the inequality-freedom nexus are to some extent conditional upon a country's political regime. When inequality is low, democracies enjoy comparatively higher levels of economic liberty, in line with the interests of a large middle-class. By contrast, economic freedom is lower in democracies (compared to strongly autocratic regimes with the same income distribution) when inequality is high. We argue that the latter finding corresponds to a system of political capitalism or captured democracy, where a powerful economic elite cooperates with politicians and bureaucrats for their mutual benefit.
\end{abstract}

JEL-Codes: D310, D720.

Keywords: income inequality, economic freedom, democratic institutions, political capitalism, middle-class, captured democracy.

\author{
Tim Krieger \\ University of Freiburg \\ Wilhelmstr. 1B \\ Germany - 79098 Freiburg \\ tim.krieger@vwl.uni-freiburg.de
}

\author{
Daniel Meierrieks \\ University of Freiburg \\ Wilhelmstr. 1B
}

Germany - 79098 Freiburg

daniel.meierrieks@vwl.uni-freiburg.de 


\section{Introduction}

A large body of empirical research suggests that economic freedom is conducive to economic growth (e.g., Islam, 1996; Wu and Davis, 1998; Gwartney et al., 1999; De Haan and Sturm, 2000; Carlsson and Lundström, 2002; Scully, 2002; De Haan et al., 2006; Justesen, 2008; Williamson and Mathers, 2011). For instance, Gwartney et al. (1999) argue that more market-friendly institutions (characterized by, inter alia, more secure property rights, greater freedom of economic exchange and less regulation) promote economic activity by facilitating innovation and entrepreneurship.

Yet, even though the benefits enjoyed by countries with more economic freedom are wellestablished, there are still substantial cross-country differences in economic freedom, with some economies (e.g., many industrialized countries such as the United States and Germany) being noticeably freer than others (e.g., many less developed countries and emerging markets in Africa, Asia and Latin America such as Nigeria, China, Brazil and Venezuela) (Gwartney et al., 2014). Previous empirical research suggests that these differences in economic freedom can be attributed to (i) differences in democratic development, with more democratic countries being more likely to promote market-friendly economic policies (De Haan and Sturm, 2003; Rode and Gwartney, 2012), (ii) differences in the speed of economic liberalization between different parts of the world, where the patterns of reform are driven by international economic competition and the policies of neighboring countries (Simmons and Elkins, 2004; Pitlik, 2007; Gassebner et al., 2011), (iii) experiences of economic crisis that consequently promote market-friendly reforms (Pitlik and Wirth, 2003), (iv) the influence of government ideology on economic policy-making (Potrafke, 2010) and (v) differences in national cultures, with cultures favoring autonomy and risk-taking being more likely to be economically free (Johnson and Lenartwoicz, 1998).

In this contribution we study the role of income inequality as another factor potentially determining country-differences in economic freedom. We argue that different societal groups (e.g., the rich, the middle-class and the poor) are interested in different levels of economic freedom. As we discuss below in more detail, those groups located at the top of the economic ladder, i.e., the elite 
or industrial incumbents ${ }^{1}$, ought to be interested in lower levels of economic freedom to discourage innovation and competition to protect their economic interests. When the distribution of economic resources within an economy is strongly skewed (i.e., when income inequality is high), those societal groups with a disproportionate access to a country's economic resources (i.e., the elite) can more easily reach their policy goals (e.g., with respect to the level of economic freedom) by converting their control over an economy's resources into political power. Potentially, this may lead to a system of political capitalism — described below in more detail—in which the industrial incumbents perpetuate their societal position by controlling the economy and economic policymaking (Holcombe, 2015). Consequently, taking a global perspective in our subsequent empirical analysis, we hypothesize that-on average-income inequality reduces economic freedom.

Elite Interest and Economic Freedom. Why would the rich be interested in constraining economic freedom in the first place? As stressed above, the empirical evidence strongly suggests that economic freedom is conducive to economic growth, especially by fostering innovation, competition and (private) investment and entrepreneurial activity (e.g., Green et al., 2002; De Haan et al., 2006; Nyström, 2008). These developments (innovation, competition etc.), however, threaten the elite's economic position, creating incentives for the elite to limit pro-market policies. Here, we do not expect the elite to completely oppose economic freedom. The elite is very likely to benefit from a certain level of economic freedom (e.g., with respect to a sound protection of their property). However, we expect industrial incumbents to favor lower levels of economic freedom vis-à-vis other societal groups (e.g., the middle-class).

First, more competition —induced by economic freedom-ought to reduce market shares and profits of established businesses controlled by the elite. For instance, Rajan and Zingales (2003) argue that industrial incumbents may oppose more liberal economic policies (e.g., trade and financial liberalization) because such policies would result in increased (domestic and international) competition and thus threaten the incumbents' market position. Second, more

\footnotetext{
${ }^{1}$ Throughout this contribution, we use the terms “elite” or "industrial incumbents” synonymously to describe those parts of the population located at the top of the income distribution, dominating the economic life. We use these terms interchangeably with others such as "the rich".
} 
competition may also make it more difficult and costly for the elite to capture and defend economic rents (e.g., from artificial monopolies or due to tariffs and quotas). ${ }^{2}$ Third, innovation-again induced by economic freedom-may depreciate the elite's investment into human and physical capital (e.g., in factories) as more innovative and efficient means of production are introduced. In other words, due to innovation industrial incumbents may fall victim to the process of "creative destruction". Finally, increased competition and innovation threaten the intergenerational transmission of wealth among members of the elite, thus further jeopardizing the long-run economic position of the elite.

From Inequality to Economic Policymaking. Having established that it is in their interest to limit economic liberty, how can the rich actually constrain economic freedom and what is the role of income inequality? Acemoglu et al. (2005) argue that the arrangement of economic institutions (e.g., the protection of property rights and the regulation of markets) is determined by the exercise of political power by different societal groups, where groups with more power are more likely to shape economic institutions in their favor. ${ }^{3}$ Importantly, in the model of Acemoglu et al. (2005) the distribution of de facto political power in turn is determined by the distribution of resources within an economy. ${ }^{4}$ A societal group that controls a disproportionate share of a country's economic resources can more prominently exercise de facto political power. Thus, as income inequality increases (i.e., when the distribution of resources within an economy becomes more

\footnotetext{
${ }^{2}$ For an early contribution to the rent-seeking literature, see, e.g., Krueger (1974).

3 The design of economic institutions matters to a country’s subsequent economic performance and future distribution of resources, which in turn matters to the subsequent arrangement of political and economic institutions, creating a tendency for institutional persistence (Acemoglu et al., 2005).

${ }^{4}$ Acemoglu et al. (2005) differentiate between de facto and de jure political power. The former refers to political power that individuals can exercise thanks to their economic might; it is rooted in a society's income distribution. De jure political power, by contrast, stems from a country's system of government, i.e., the design of its political institutions. Acemoglu et al. (2005) argue that de jure political power may also influence economic institutions. We shall discuss the nexus between a country's political institutions and the inequality-economic freedom relationship in more detail in Section 4.
} 
uneven), a rich elite is more likely to accumulate de facto political power to influence economic institutions in their favor. At the same time, rising inequality is anticipated to reduce the economic and thus political clout of the poorer segments of society. For instance, rising inequality may create political fatigue among lower-income individuals because it may become too costly for them to coordinate their actions and successfully form political coalitions to make their voices heard (Solt, 2008).

As stressed above, to protect their economic interests the industrial incumbents are expected to limit economic freedom, i.e., to promote policies that create market entry barriers, prevent innovation as well as carve out and defend rent-extracting opportunities. For example, such policies may include excessive regulation (red tape), high tariffs to protect domestic markets from foreign competition, deliberately imperfect credit markets (where the elite itself may gain access to finance through personal relationships rather than financial markets) or restrictions on the international flow of capital (capital controls) to discourage foreign investment. The exercise of de facto political power to push such policies is usually associated with lobbying, including, e.g., the exercise of political influence via political parties, special interest groups, the offering of private sector jobs to politicians and government employees in return for favorable policy choices (the so-called "revolving door") and through campaign contributions and other forms of payments to politicians. For instance, Grossman and Helpman (1994) develop a model in which special interest groups use political contributions to shape trade policies in their favor (e.g., to restrict free trade). Arguably, the elite is in the best position to promote its interests by influencing political decision-making, given that they have the most to offer to politicians and bureaucrats acting as selfish maximizers of their own (rather than social) utility. ${ }^{5}$ Holcombe (2015: 41) calls a potential ending-point of the interaction between economic power in the hands of the elite, their desire to perpetuate their socio-economic position in society by curtailing economic freedom and the susceptibility of self-interested policy-makers to payments from the wealthy political capitalism:

\footnotetext{
${ }^{5}$ Theoretically, one may interpret the relative success of the rich compared to the poor in terms of a Tullock contest model (e.g., Tullock 1967). The relatively larger investments of the rich into rent-seeking activities give them a head start in winning the contest for political power.
} 
"Political capitalism [means that] the economic and political elite cooperate for their mutual benefit. The economic elite influence the government's economic policies to use regulation, government spending, and the design of the tax system to maintain their elite status in the economy. The political elite are then supported by the economic elite which helps the political elite maintain their status; an exchange relationship that benefits both the political and economic elite.”

Reverse Causation. Importantly, even though we can argue that inequality affects economic freedom, the opposite may also be true. That is, economic freedom may also affect inequality. Here, the nature of this effect is a priori unclear. The optimistic view concerning the effect of economic freedom on inequality suggests that freedom reduces inequality by unleashing theassumed to be inherently fair-forces of the free market. For instance, Berggren (1999) argues that the poor are more motivated to make use of economic freedom (e.g., by establishing new businesses), implying that more economic freedom leads to less inequality. Indeed, empirical evidence provided by Berggren (1999) and Scully (2002) suggests that higher levels of economic freedom are associated with lower income inequality. Other voices, however, suggest that economic liberty leads to more income inequality. Here, more economic freedom (e.g., in the form of deregulation) may disproportionately benefit the talented who can capitalize on the opportunities economic freedom creates, causing more income inequality (Sturm and De Haan, 2015). Indeed, Carter (2006) finds that more economic freedom leads to less equity. In a more general sense, the argument could then be made that inequality is inherent to a market-economy system. As put by Muller (2013: 30):

"Inequality is an inevitable product of capitalist activity, and expanding equality of opportunity only increases it-because some individuals and communities are simply better able than others to exploit the opportunities for development and advancement that capitalism affords.”

The consequences of a potential effect of economic freedom on inequality (which could be positive or negative) for our study are twofold. First, we need to take endogeneity-which may be a consequence of, inter alia, feedback/reverse causation — seriously when estimating the effect of inequality on economic freedom. Thus, in the following we shall also resort to dynamic panel models using the difference- and system-GMM (generalized methods of moments) estimator that 
are an appropriate choice when endogeneity is a concern (e.g., Bond, 2002; Roodman, 2009). Second, the potentially complex interaction between economic liberty and equity motivates an empirical study of the causal relationship between inequality and economic freedom by means of a panel causality analysis. Importantly, both issues — endogeneity and causation—have so far been disregarded in the few studies that have analyzed the inequality-economic freedom nexus in the past.

The rest of this contribution is organized as follows. In Section 2 we analyze the causal relationship between inequality and economic freedom. Here, we also discuss the data used to operationalize both concepts. In Section 3 we examine whether our panel causality findings are robust to the inclusion of additional controls, while in Section 4 we analyze whether democratic development matters to the inequality-freedom nexus. Section 5 concludes.

\section{Inequality and Economic Freedom: Panel Causality Evidence}

As discussed in the introduction, the causal relationship between inequality and economic freedom is a priori unclear. For one, more income inequality may lead to less economic freedom. For another, there may be a causal influence of economic freedom on income inequality. Furthermore, it may be possible that inequality and economic freedom are jointly determined (bidirectional causation).

\subsection{Data}

To empirically investigate causality in the inequality-freedom nexus, we collect panel data for 100 countries for the 1971-2010 period. ${ }^{6}$ As data on economic freedom is only available every five years, we average the data to create eight consecutive (non-overlapping) 5-year periods. The summary statistics are reported in Table 1.

\section{- Table 1 here-}

Economic Freedom. The data on economic freedom come from the Economic Freedom of the World Dataset published by the Fraser Institute (Gwartney et al., 2014). The concept of economic freedom is discussed by Gwartney et al. (2014: 1) as follows:

\footnotetext{
${ }^{6}$ A country list is provided in the appendix.
} 
“The cornerstones of economic freedom are (1) personal choice, (2) voluntary exchange coordinated by markets, (3) freedom to enter and compete in markets, and (4) protection of persons and their property from aggression by others. Economic freedom is present when individuals are permitted to choose for themselves and engage in voluntary transactions as long as they do not harm the person or property of others."

Accordingly, the Fraser Institute index of economic freedom measures economic freedom related to five major areas: the size of the government, the functioning of the legal system and the security of property rights, sound money, the freedom to trade internationally and regulation (Gwartney et al., 2014: 3). While these five components constitute the summary economic freedom index, the components in turn make use of 42 sub-components and distinct variables. ${ }^{7}$ The summary index ranges from 0 (no economic freedom) to 10 (total economic freedom). While this index may be subject to criticism (e.g., concerning ideological bias), De Haan et al. (2006: 182) still come the conclusion that the index—not least because it is available for a large country panel—“is both reliable and useful”.

For our empirical study, we make one important adjustment. When constructing our adjusted economic freedom index we only consider information provided by the Economic Freedom of the World Dataset on economic freedom related to legal structure and the security of property rights, the freedom to trade internationally and the regulation of credit, labor and business. That is, we do not consider those elements of the original Fraser Institute index related to the size of the government and sound money. Here, we follow, e.g., De Haan and Sturm (2000: 221-223) and Sturm and De Haan (2015). These authors argue that both government size and sound money (i.e., the costs of inflation) measure redistribution. Government size is primarily related to taxation and government transfers, while inflation can be regarded as another form of taxation. Conceptually, however, it is unclear whether more taxation and redistribution always result in less economic freedom (as it is implied by the original Fraser Institute index). For instance, tax income may be invested in public goods that enable the proper functioning of markets (e.g., the legal system) or

\footnotetext{
${ }^{7}$ For instance, to construct the first component of the economic freedom index (government size) information on, inter alia, government consumption, tax rates and the share of government subsidies and transfers to total economic activity is used.
} 
to overcome certain frictions that constrain economic exchange (e.g., through infrastructure investment), both of which can be expected to eventually lead to more economic activity by the private sector and more economic freedom. By using an adjusted economic freedom index, we disregard the (contested) issue of redistribution, instead focusing on those elements of economic freedom more clearly associated with market-friendliness (measuring, e.g., external and internal openness of the markets, the protection of property rights and the freedom of economic initiative and contracting).

Income Inequality. Data for our second variable of interest, income inequality, is drawn from the Standardized World Income Inequality Database of Solt (2009). This database incorporates data from other cross-country datasets on inequality (e.g., the University of Texas Inequality Project, the United Nations University's World Income Inequality Database and the Luxembourg Income Study) to provide uniform inequality data for the widest possible coverage across countries and over time (Solt, 2009). The database reports the Gini coefficient, the standard indicator of income inequality, for net income, i.e., after taxes and transfers, and for gross income, i.e., for income before taxes and transfers. To make our analysis consistent, we choose the Gini coefficient calculated for gross income, given that using this variable is again expected to minimize the influence of taxation/redistribution. The values of the Gini coefficient range from 0 (total income equality) to 100 (total income inequality). As argued above, we interpret a country's income distribution as an indication of the distribution of resources with an economy. As income inequality increases, a rich elite is more likely to accumulate economic clout that is consequently converted into de facto political power to influence economic institutions in their favor. Thus, we expect higher levels of income inequality to be associated with less economic freedom, the latter being in the interest of the elite.

For the 2006-2010 period, Figure 1 provides a first illustration of how economic freedom (measured by our adjusted economic freedom index) and income inequality (measured by the gross income Gini coefficient) are related. The figure suggests that higher income inequality (produced at the market-level) is indeed associated with less economic freedom (i.e., fewer free-market policies). In the following sub-section, we want to assess whether this relationship is statistically robust and whether causation runs from inequality to freedom, vice versa or whether both variables are jointly determined. 


\section{-Figure 1 here-}

\subsection{Empirical Methods}

To test for causality in the inequality-freedom nexus, we follow Holtz-Eakin et al. (1988) and fit a series of time-stationary bivariate panel vector-autoregressive (PVAR) models of the following form:

$$
\begin{aligned}
G I N I_{i t} & =\propto_{0}+\sum_{l=1}^{m} \propto_{l} G I N I_{i t-l}+\sum_{l=1}^{m} \delta_{l} E F_{i t-l}+\tau_{t}+\mu_{i}+u_{i} \\
E F_{i t} & =\beta_{0}+\sum_{l=1}^{m} \beta_{l} E F_{i t-l}+\sum_{l=1}^{m} \gamma_{l} G I N I_{i t-l}+\tau_{t}+\eta_{i}+v_{i}
\end{aligned}
$$

Here, the variable GINI and EF refer to the market-level Gini coefficient and the level of economic freedom, respectively, in country $i$ in 5-year interval $t$. Besides the intercepts ( $\alpha_{0}$ and $\beta_{0}$ ), the panel VAR also includes lags of the dependent and independent variable up to lag length $m$, period dummies $\tau_{t}^{8}$, country-specific fixed effects $\left(\mu_{i} \text { and } \eta_{i}\right)^{9}$ and the disturbances $\left(u_{i}\right.$ and $\left.v_{i}\right)$.

To test for the causal relationship between income inequality and economic freedom, we resort to the concept of Granger causality (Granger, 1969). According to Granger’s (1969: 428) definition

\footnotetext{
${ }^{8}$ In contrast to Holtz-Eakin et al. (1988), we include a set of time dummies because this makes it more likely that there is no correlation across individuals in the idiosyncratic disturbances, meaning that an important assumption of the Arrelano-Bond autocorrelation tests and the robust estimates of the standard errors used in the context of the dynamic panel difference- and systemGMM estimator is met. The inclusion of time dummies is also recommended by Roodman (2009: 128). Running the panel causality tests without the time dummies, however, yields similar findings (results available upon request).

${ }^{9}$ Including country fixed-effects ought to control for time-invariant (and possibly, unobservable) variables that may possibly matter to the inequality-freedom nexus. For instance, Gassebner et al. (2011) argue that we should see higher levels of economic freedom in a country when it is geographically or culturally proximate to countries that also have liberalized economies. Similarly, Johnson and Lenartwoicz (1998) argue that cross-country differences in culture (which do not change over time and/or are unobservable) may explain differences in economic freedom.
} 
of causality, there is a causal effect of one variable (independent variable) on another (dependent variable) if prediction of the dependent variable is improved by also including information on the independent variable. To study Granger causation from economic freedom to income inequality in a panel framework, we run model (1.1) and assess whether $\delta_{l}=0$ for a set of lags of order $l$ to $m$ by means of a joint $F$-test or $\chi^{2}$-test for zero coefficients. Similarly, to assess whether income inequality Granger-causes economic freedom, we consider model (1.2) and test whether $\gamma_{l}=0$ for lags $l$ to $m$ via a joint $F$ - or $\chi^{2}$-test. In both cases, rejecting the null hypothesis of zero coefficients implies rejection of the null hypothesis of Granger non-causality (Holtz-Eakin et al., 1988).

Given that the number of available 5-year periods is rather short $(T=8)$, we only fit PVAR(1) and PVAR(2) models. We first estimate the models (1.1) and (1.2) using the least-square dummy variable $(L S D V)$ estimator, where the country-specific effects directly enter the model, thus allowing for different country intercepts. However, it is well known that the LSDV estimator generates biased and inconsistent estimates in a dynamic setting when $T$ is small and when explanatory variables are not strictly exogenous (Bond, 2002).

Thus, we also use the difference-GMM and system-GMM estimators which account for the concerns of panel analysis (i.e., presence of fixed-effects and potential endogeneity of regressor), while avoiding the aforementioned dynamic panel bias. That is, these estimators are designed for panels with many units (in our case, countries, $N$ ) and small $T$, with the left-hand-side variable being dynamic (i.e., depending on its own past realizations), the independent variables not being strictly exogenous (i.e., being correlated with past and possibly current realizations of the error) and the model including fixed individual effects (Roodman, 2009). The GMM estimators use "internal" instruments (based on lagged values of the instrumented variables) to overcome the aforementioned sources of bias; here, we may either use only lagged levels of the instrumented variables (difference-GMM) or both lagged levels and lagged first-differences (system-GMM) to construct an appropriate instrument set. Both GMM estimators are described in, inter alia, HoltzEakin et al. (1988), Arrelano and Bond (1991), Arrelano and Bover (1995), Blundell and Bond (1998), Bond (2002) and Roodman (2009).

Both GMM estimators rely on critical assumptions which must hold for the GMM estimates to be valid. First, the selected instrument set needs to be the exogenous (e.g., Roodman, 2009). We therefore report the results of the Hansen test for instrument validity (over-identification 
restrictions); not rejecting the null hypothesis of joint validity of the instruments suggests the GMM estimates are sound in this regard. Roodman (2009: 128) suggests to limit the instrument count to not exceed $N$, as "instrument proliferation can overfit endogenous variables and fail to expunge their endogenous components”, while at the same time weakening the power of the Hansen test designed to detect a non-valid instrument set. Therefore, we always report the instrument count and make sure that instrument proliferation does not become a problem by restricting the number of instruments accordingly. Finally, we also report the Arrelano/Bond test for serial correlation. Arrelano and Bond (1991) argue that some lags of the instrumented variables are rendered invalid as instruments when there is autocorrelation in the idiosyncratic disturbances. Regarding the expected test results, by construction there should be evidence for AR(1) serial correlation behavior; however, higher-order serial correlation should not be detected, thus ensuring that the assumption of serial independence in the original errors holds (Arrelano and Bond, 1991; Roodman, 2009).

\subsection{Empirical Results}

As already stressed above when introducing the PVAR specification, all variables considered in the bivariate PVAR system need to be stationary to correctly test for Granger causality (Granger, 1969; Holtz-Eakin et al., 1988). The use of integrated data series would raise questions associated with spurious regression and, possibly, co-integration. Therefore, we first test for the order of integration of the inequality and freedom variables by means of the Fisher-type PP- (Choi, 2011) and the LLC (Levin et al., 2002) panel unit root tests. As shown in Table 2, there is strong evidence that both data series are indeed $I(0)$, i.e., stationary. That is, it is appropriate to test for Granger causality using the framework outlined above. There is no need to consider panel co-integration or data transformation.

\section{—Table 2 here-}

The panel causality test results are reported in Table 3. Irrespective of which empirical method we employ and lag length we choose, we cannot reject the null hypothesis of Granger non-causality for the effect of economic freedom on income inequality. Here, the diagnostic checks related to the difference- and system-GMM estimates generally suggest that the models (and the underlying instrument set) are well-specified. Thus, the empirical results do not suggest that inequality (produced by the market-place) is a consequence of economic freedom. Our findings are consistent 
with Sturm and De Haan (2015) who also show that income inequality is not a function of economic freedom.

Conversely, considering the Granger-causal effect of income inequality on economic freedom, regardless of which empirical method and lag length we choose, we always reject the null hypothesis of Granger non-causality. Again, the diagnostic checks related to the difference- and system-GMM estimates suggest that the models are well-specified. That is, there is evidence that income inequality Granger-causes economic freedom but not vice versa. This finding is consistent with our main hypothesis of an effect of income inequality on economic freedom. In line with the model of Acemoglu et al. (2005), more income inequality (as indicated by the market-level Gini coefficient) means that the elite has greater control over a country's economic resources and is consequently better able to convert this economic power into de facto political power to influence the regulation of the market-place (as indicated by the level of economic freedom) in their favor. For instance, this may mean to curtail international trade or access to capital markets through excessive regulation, which consequently is expected to limit opportunities for innovation and competition that may otherwise threaten the elite's economic position.

\section{- Table 3 here-}

\section{Inequality as a Determinant of Economic Freedom}

As already discussed in the introduction, the level of economic freedom may also be determined by factors other than income inequality. Thus, in the following we examine whether the main finding from the causality analysis-income inequality affects economic freedom-is robust to the inclusion of further controls that may also affect economic freedom. The summary statistics of these additional variables are reported in Table 1.

\subsection{Additional Control Variables}

First, we now also consider the influence of democratic institutions. The level of democracy is measured by the (rescaled) polity score drawn from the POLITY IV Dataset (Marshall et al., 2014), with values ranging from 0 (full autocracy) to 10 (full democracy). Consistent with existing research (e.g., De Haan and Sturm, 2003; Rode and Gwartney, 2012), we expect democracy to be positively related to the level of economic freedom. For instance, democratic regimes are more likely to exhibit the legitimacy necessary to carry out economic reforms that are (at least in the 
short run) potentially costly (De Haan and Sturm, 2003). Also, democratic regimes may be able to better manage any socio-economic fallout (e.g., increases in unemployment that result from increased external competition) associated with higher levels of economic freedom.

Second, we control for the effect of per capita income, measured in (logged) constant 2005 U.S. dollars, on economic freedom. The data come from the PENN World Tables (Feenstra et al., 2015). As already hinted at in the introduction, economic freedom may promote economic development (for a review see De Haan et al., 2006). At the same time, however, there may also be an effect of economic development on economic freedom. For instance, Justesen (2008) argues that poor economies may have stronger incentives to pursue more market-friendly economic policies to unleash the growth potential associated with them.

Third, we include a control variable for economic openness. Openness is operationalized by an index that accounts for cross-border flows of goods, services and capital (FDI, portfolio investment). A larger index coincides with a higher level of economic openness. The data come from an update of the KOF Globalization Index Dataset developed by Dreher (2006). Potentially, differences in economic globalization may account for differences in economic freedom. For instance, a higher level of economic openness ought to coincide with more external competition, consequently producing additional pressures on countries to develop more market-friendly economic institutions (e.g., Sachs and Warner, 1995; Simmons and Elkins, 2004). Thus, we may expect economic openness to be positively related to economic freedom.

Finally, in some specifications we also control for inflation, measured by the growth rate of the GDP implicit deflator, with the data being drawn from the World Development Indicators (World Bank, 2014). For instance, Pitlik and Wirth (2003) argue that poor macroeconomic conditions (e.g., an inflation crisis) create incentives for economic reform (resulting in higher levels of economic freedom). Therefore, we expect inflation to positively predict economic freedom.

Furthermore, in some specifications we also control for the influence of government ideology. Here, ideology is measured by the share over a given 5-year period during which the government is dominated by left-wing parties. The data on government ideology come from an update of the Database of Political Institutions (Beck et al., 2001). Potrafke (2010) argues that pro-market policies (i.e., higher levels of economic freedom) can be regarded as a right-wing project because 
they coincide with right-wing ideas of small government and the protection of individual gains from talent. Left-wing parties, by contrast, may be more likely to favor state interventionism and control over the economy (Potrafke, 2010). Therefore, we expect left-wing government incumbency to negatively predict economic freedom.

\subsection{Empirical Results}

The empirical results from a series of difference- and system-GMM estimations considering the effect of inequality and the controls on economic freedom are reported in Table $4 .{ }^{10}$ Considering our main variable of interest, we find that the market-level Gini coefficient exerts a negative effect on economic freedom. This effect is robust to different estimation techniques and model specifications and also consistent with the earlier reported panel causality test results. The finding is also in line with our expectations voiced in the introduction. Correspondingly, we interpret our finding of a negative impact of higher levels of income inequality on economic freedom as evidence that more economic power in the hands of the elite (as indicated by a larger market-level Gini coefficient) translates into more de facto political power (in the form of lobbying, campaign contributions etc.) used to further curtail economic freedom to protect the elite's economic interests.

\section{- Table 4 here-}

Next, we briefly consider the results for the control variables. ${ }^{11}$ First, we find that higher levels of democracy are robustly associated with higher levels of economic freedom. This finding speaks to

${ }^{10}$ Given that the evidence of a causal effect of income inequality on economic freedom is strongest for a lag length of $m=1$, we focus on this lag length. Note that we also run static and dynamic LSDV estimations as a robustness check. Given the potential biasedness of these estimations, we only report them in the appendix. The LSDV estimates are generally in line with our main findings reported in the text.

11 We are well aware that all control variables we selected are potentially endogenous to a country's level of economic freedom. For instance, feedback may exist between a country’s income level and level of economic freedom. Thus, all control variables (expect the time fixedeffects) are treated as potentially endogenous in the difference- and system-GMM estimations, meaning that the instrument sets are amended accordingly. Treating the additional covariates as 
evidence reported in De Haan and Sturm (2003), De Haan et al. (2006) and Rode and Gwartney (2012). For instance, democratic regimes may be better suited to manage the distributional conflicts potentially resulting from economic liberalization. Second, we find that past levels of economic freedom positively predict present ones. This may indicate the presence of path dependence. Importantly, the estimated autoregressive coefficients do not approach unity, making a weak instrument problem less likely (Bond, 2002). Third, considering the role of economic openness, the system-GMM (but not the difference-GMM) estimates suggest that higher levels of openness are associated with more economic freedom. This finding corresponds to the ideas of Sachs and Warner (1995) and Simmons and Elkins (2004) that more international competition (resulting from higher levels of economic openness) makes the adaption of more market-friendly economic institutions more likely. Finally, we find no evidence that per capita income, inflation and government ideology share a statistically meaningful relationship with the level of economic freedom.

\section{Does Democracy Matter to the Inequality-Freedom Nexus?}

In the model of Acemoglu et al. (2005), inequality determines the distribution of de facto political power which in turn determines the design of economic institutions (i.e., the level of economic freedom). The evidence reported so far speaks to this mechanism. However, Acemoglu et al. (2005) argue that the design of economic institutions is also determined by the distribution of de jure political power in a society, which in turn is rooted in the design of a society's political institutions. Indeed, in Section 3 we reported evidence that more democratic institutions result in higher levels of economic freedom. Following the model by Acemoglu et al. (2005), this may suggests that the exercise of de jure political power also matters to economic liberty.

Generally speaking, it is then plausible that the role income inequality plays in economic freedom (i.e., through the exercise of de facto political power) depends on a country’s political institutions (i.e., the exercise of de jure political power). Specific combinations of inequality and political institutions may make it more (or less) likely that the elite can achieve its policy goals. Arguably, different political institutional arrangements provide different opportunities to influence economic

strictly exogenous and/or predetermined, however, does not change the main results reported in the text (results available upon request). 
institutions. For instance, when de jure political institutions characterize a country as a democracy, it may be easier to convert economic power into "political currency” because political parties in democracies may be especially responsive to various forms of payments by the economic elite. At the same time, different de jure political institutions can also be expected to provide different incentives to pursue policies that favor one's interest (i.e., with respect to the elite, to pursue antiliberal economic policies). Finally, different political institutions may matter insofar as the interests of other political players have to be considered, given that these interests may interfere (align) with the interests of the elite and therefore make it more difficult (less difficult) to influence the design of economic institutions. Most importantly, the pro-market interests of a middle-class that makes itself heard in a democracy may run counter to the interests of the industrial incumbents who want to curtail economic freedom.

To empirically analyze whether the effect of income inequality on economic freedom is indeed conditional on the influence of domestic political institutions, we amend our baseline model with a multiplicative interaction term (where inequality and democracy are multiplied). We report the regression results in Table 5. Including all constitutive terms in an interaction model may lead to multicollinearity, meaning that standard error estimates tend to grow and the regression coefficients associated with the interaction model are less likely to be statistically significant at conventional levels (Brambor et al., 2005). Multicollinearity also affects our estimates. ${ }^{12}$ Joint Ftests, however, suggest that the inclusion of all constitutive terms of the interaction model is statistically meaningful. More importantly, the constitutive elements of the interaction term (i.e., the variables measuring inequality and democracy) can no longer be interpreted as unconditional or average effects (Braunmoeller, 2004). In other words, the analytical value of the regression output is limited. Instead, as advised by, e.g., Brambor et al. (2005), we present and discuss below graphical representations of the marginal and interaction effects calculated from the GMMestimates.

\section{- Table 5 here-}

\footnotetext{
12 The mean variance inflation factor of inequality, democracy and their interaction is 30.41, well above the critical value of 10 that indicates a severe multicollinearity problem.
} 
To get a better understanding of how a country's level of democratic development mediates the effect of income inequality on economic freedom, Figure 2, using the system-GMM estimates reported in Table 5 and holding all other covariates at their respective means, visualizes the related marginal effects of inequality as they change with the level of democracy. There is no evidence that income inequality influences economic freedom in strongly autocratic regimes. However, we find that income inequality exerts a statistically significant and negative effect on economic freedom once the democracy variable takes on a value of at least three. ${ }^{13}$ According to Marshall et al. (2014), a value of three of the democracy variable corresponds to a political system called “closed anocracy”, i.e., a political system exhibiting traits of democracies and autocracies, where political competition exists but usually only emerges from within the ruling elite. The more democratic a country becomes, the stronger the conditional marginal effect of inequality.

\section{-Figure 2 here-}

Figure 3 visualizes how various combinations of income inequality at the market-level and democracy affect the level of economic freedom a country enjoys. Differentiating between strongly autocratic and democratic regimes on the one hand and different levels of income inequality on the other hand, four distinct cases emerge.

\section{-Figure 3 here-}

Case 1: Autocracy. Many countries in our sample experienced at least some episodes of strong authoritarianism (e.g., Chile, China, Iran, Tunisia). As shown in Figure 3, when a country is governed by a strongly autocratic regime, there is virtually no effect of income inequality (produced in the market-place) on economic freedom. Irrespective of the level of inequality, from our model we always expect (holding the other covariates at their means) a level of economic freedom of approximately six. This finding suggests that the opportunities for the elite to shape economic institutions in their favor are limited when political power is strongly centralized. ${ }^{14}$ First,

\footnotetext{
${ }^{13}$ This corresponds to a value of -4 of the original (not rescaled) Polity2 score.

${ }^{14}$ It is of course also possible that the economic elite is congruent with the political elite. For instance, in Egypt the military has routinely held tight control over the country's economic and political life. When the economic elite is-largely-identical with the political elite, we also do
} 
autocratic rulers are expected to be less responsive to payments by the elite, given that they already have ample opportunities to generate income (e.g., through arbitrary taxation) and extract rents (e.g., from natural resources). Second, an autocratic ruler may be interested in allowing for at least some economic freedom to promote some productivity, so as to make sure that the ruler's stream of income and rents (and thus the ruler's own consumption) is guaranteed. This may further complicate efforts by the elite to curtail economic freedom. Third, the rich themselves may have fewer incentives to reduce economic freedom. Arguably, unconstrained autocratic power invites kleptocratic behavior by the ruler. The accompanying risk of expropriation may mean that the elite has interest in a form of "minimal state" that provides at least some amount of economic security (e.g., by protecting property rights or regulating government interference into the economic life).

Case 2: Moderate Income Inequality. As shown in Figure 3, when the market-level Gini coefficient hovers between 45 and 50, there is little difference in the estimated level of economic freedom in democracies, anocracies and autocracies. Many countries in our dataset are located in this spectrum. One could argue that in such a situation there is no interest group clearly coming out on top. Below, we discuss what happens to economic freedom when either the middle-class (Case 3) or the elite (Case 4) can dominate the political process instead.

Case 3: Middle-Class Democracy. Figure 3 also shows that democracies enjoy-compared to autocratic regimes-higher levels of economic freedom when income inequality is low (Gini coefficient $<40$ ). For our dataset, this was the situation in countries such as Belgium, New Zealand and Japan during the 1971-2010 period. Potentially, the combination of relatively low inequality and democratic institutions makes it more likely that the country exhibits an (ideal) majoritarian electoral rule, where policies that are most preferred by the electorate (i.e., the median voter) are actually implemented (Gilens and Page, 2014). First, the economic elite (as signaled by low inequality) is more likely to be weak, thus having comparatively fewer opportunities to influence policy-making. By contrast, other interest groups associated with a broad middle-class are more likely to form successful coalitions that may implement policies that in fact run counter to the

not expect to see that the level of economic freedom is sensitive to income inequality because in such cases the elite can be expected to simply use its control over the de jure political institutions to shape economic institutions in their favor in a cost-efficient way. 
elite's interests. Indeed, Easterly (2001) and Loyaza et al. (2012) show that countries with large middle-classes (i.e., with lower inequality) are more likely to prefer pro-growth economic policies that emphasize economic freedom. For instance, Loyaza et al. (2012) show that a larger middle class negatively correlates with restrictions to trade (tariffs) and to credit market access. At the same time, the middle-class can also use the force of the government to weaken the elite's access to economic rents (Holcombe, 2015), thereby further undermining the economic clout of the elite to influence the political process.

Case 4: Political Capitalism. Finally, the results visualized in Figure3 indicate that democracies see lower levels of economic freedom compared to autocracies when income inequality is high (Gini coefficient $>55$ ). Considering our dataset and time horizon, this was the situation in a number of developing and emerging economies such as Brazil, South Africa and Botswana. Under such circumstances, the elite ought to be powerful enough to shape economic institutions in their favor. This finding corresponds to Holcombe's (2015) system of political capitalism in which the economic and political elites cooperate for their mutual benefit, suggesting that the economic elite uses payments and other forms of favors to the political elite to protect their economic interests. Acemoglu and Robinson (2008: 283) call these circumstances a captured democracy, in which “democratic political institutions emerge and survive for extended periods of time, but they are captured by the elite, which is able to impose its favorite economic institutions”. They argue that the elite can, by capitalizing on its smaller size minimizing collective action problems and being motivated by greater expected gains, influence economic institutional arrangements through means such as lobbying, bribery and perhaps even the use of extralegal force. Finally, our Case 4 also matches Gilens and Page (2014: 566) model of economic-elite domination in which "policy making is dominated by individuals who have substantial economic resources, i.e., high levels of income or wealth—including, but not limited to, ownership of business firms.” Interestingly, Gilens and Page (2014) find that the economic-elite domination model is even relevant to the United States, a (perceived) beacon of democracy and free-market capitalism. Investigating how different voter preferences and interest groups influenced 1,779 instances of proposed policy changes between 1981 and 2002, they come the following conclusion (Gilens and Page, 2014: 575-576): 
"When the preferences of economic elites and the stands of organized interest groups are controlled for, the preferences of the average American appear to have only a minuscule, near-zero, statistically non-significant impact upon public policy. [...] When a majority of citizens disagrees with economic elites or with organized interests, they generally lose.”

In other words, democratic institutions do not necessarily lead to favorable outcomes-higher levels of economic freedom-when elites are sufficiently strong. Rather, a powerful elite seems to be more successful in advancing its interests in democratic rather than autocratic settings. For instance, this may be a consequence of the fact that democracies offer various pathways to exert political influence (e.g., via multiple political parties vying for political contributions), while at the same time politicians in democracies are also more susceptible to elite payments than kleptocratic rulers in autocracies. Furthermore, as found by Solt (2008), income inequality creates political and voter fatigue especially among the people with lower incomes (e.g., because it is too costly for them to coordinate and make their voices heard). Thus, the dominant role of the elite may be further strengthened by the depressing effect economic inequality has on political interest among the poor and their participation in elections (Solt, 2008).

\section{Conclusion}

In this contribution we study the interaction between income inequality and economic freedom for a panel of 100 countries for the 1971-2010 period, also accounting for the potential role political institutions may play in the inequality-economic freedom nexus. Our results can be summarized as follows. First, we find evidence that income inequality Granger-causes economic freedom, while causation does not run in the other direction. Second, the effect of income inequality on economic freedom is negative and robust to different sets of controls and estimation techniques. Third, the dynamics of the inequality-freedom nexus are to some extent conditional upon a country's political institutions. In particular, when inequality is low, democracies enjoy higher levels of economic liberty. By contrast, when inequality is high, the level of economic freedom in democracies is actually lower than in strongly autocratic regimes with the same level of inequality.

Our explanation for these empirical patterns emphasizes the role of rich industrial incumbents in shaping economic institutions by exercising de facto political power. We argue that the economic elite uses this power to get policies implemented that protect their economic interests; usually, 
such policies ought to discourage competition and innovation and thus be anathema to economic freedom. Our results suggest that elite influence is the strongest when income inequality is high (signaling the presence of a strong elite) and political institutions are democratic and open (giving ample opportunities and incentives for the elite to shape institutions in their favor). These circumstances are consistent with theoretical outcomes previously described as "political capitalism”, captured democracy” or “economic-elite domination”.

Our panel causality study evidence suggests that pro-market economic institutions do not per se influence (Granger-cause) economic inequality. However, other factors such as technological progress, trade and financial globalization, the international division of labor, political instability and the advent of financial crises may substantially influence the distribution of income (e.g., Roine et al., 2009; Jaumotte et al., 2013), which in turn may strengthen the economic clout of certain societal groups and thus consequently their de facto political power. Particularly when shocks and long-run trends favor the position of the elite, there may be a real danger that economic freedom is consequently constrained, which—ultimately—is also anticipated to jeopardize longrun economic growth. This ought to create sufficient incentives to limit the ways through which the economic elite can exercise political influence. For instance, related policies may include stricter laws on campaign contributions, the introduction or extension of cooling periods to inhibit revolving door behavior and more stringent transparency regulation. Such rules may even be enshrined in national constitutions as a strict signal against any overwhelming influence of the economic elite and their potential collusion with policymakers.

\section{References}

Acemoglu, D., Johnson, S., Robinson, J.A. (2005). Institutions as a fundamental cause of long-run growth. In: Aghion, P., Durlauf, S. (eds), Handbook of Economic Growth. Elsevier, Amsterdam, pp. 386-472.

Acemoglu, D. Robinson, J.A. (2008). Persistence of power, elites, and institutions. American Economic Review 98, 267-293.

Arrelano, M., Bond, S.R. (1991). Some tests of specification for panel data: Monte Carlo evidence and an application to employment equations. Review of Economic Studies 58, 277-297.

Arellano M., Bover, O. (1995). Another look at the instrumental-variable estimation of errorcomponents models. Journal of Econometrics 68, 29-52. 
Beck, T., Clarke, G., Groff, A., Keefer, P., Walsh, P. (2001). New tools in comparative political economy: The Database of Political Institutions. World Bank Economic Review 15, 165-176.

Berggren, N. (1999). Economic freedom and equality: Friends or foes? Public Choice 100, 203223.

Blundell R.W., Bond S.R. (1998). Initial conditions and moment restrictions in dynamic panel data models. Journal of Econometrics 87, 115-143.

Bond, S.R. (2002). Dynamic panel data models: A guide to micro data methods and practice. Portuguese Economic Journal 1, 141-162.

Brambor, T., Clark, W.R., Golder, M. (2005). Understanding interaction models: Improving empirical analyses. Political Analysis 13, 1-20.

Braunmoeller, B.F. (2004). Hypothesis testing and multiplicative interaction terms. International Organization 58, 807-820.

Carlsson, F., Lundström, S. (2002). Economic freedom and growth: Decomposing the effects. Public Choice 112, 335-344.

Carter, J.R. (2006). A note on economic freedom and income inequality. Public Choice 130, 163177.

Choi, I. (2001). Unit root tests for panel data. Journal of International Money and Finance 20, 249272.

De Haan, J., Lundström, S., Sturm, J.-E. (2006). Market-oriented institutions and policies and economic growth: A critical survey. Journal of Economic Surveys 20, 157-191.

De Haan, J., Sturm, J.-E. (2000). On the relationship between economic freedom and economic growth. European Journal of Political Economy 16, 215-241.

De Haan, J., Sturm, J.-E. (2003). Does more democracy lead to greater economic freedom? New evidence for developing countries. European Journal of Political Economy 19, 547-563.

Dreher, A. (2006). Does globalization affect growth? Evidence from a new index of globalization. Applied Economics 38, 1091-1110.

Easterly, W. (2001). The middle class consensus and economic development. Journal of Economic Growth 6, 317-335.

Feenstra, R.C., Inklaar, R., Timmer, M. (2015). The next generation of the Penn World Table. American Economic Review, forthcoming.

Gassebner, M., Gaston, N., Lamla, M.J. (2011). The inverse domino effect: Are economic reforms contagious? International Economic Review 52, 183-200. 
Gilens, M., Page, B.I. (2014). Testing theories of American politics: Elites, interest groups, and average citizens. Perspectives on Politics 149, 564-581.

Granger, C.W.J. (1969). Investigating causal relations by econometric models and cross-spectral methods. Econometrica 37, 424-438.

Green, S., Melnyk, A., Powers, D. (2002). Is economic freedom necessary for technology diffusion? Applied Economic Letters 9, 907-910.

Grossman, G.M., Helpman, E. (1994). Protection for sale. American Economic Review 84, 833850.

Gwartney, J.D., Lawson, R.A., Hall, J. (2014). Economic Freedom of the World: 2014 Annual Report. The Fraser Institute, Vancouver, B.C.

Gwartney, J.D., Lawson, R.A., Holcombe, R.G. (1999). Economic freedom and the environment for economic growth. Journal of Institutional and Theoretical Economics 155, 643-663.

Holcombe, R.G. (2015). Political capitalism. Cato Journal 35, 41-66.

Holtz-Eakin, D. Newey, D., Rosen, H.S. (1988). Estimating vector autoregresssions with panel data. Econometrica 56, 1371-1395.

Islam, S. (1996). Economic freedom, per capita income and economic growth. Applied Economics Letters 3, 595-597.

Jaumotte, F., Lall, S., Papageorgiou, C. (2013). Rising income inequality: Technology, or trade and financial globalization? IMF Economic Review 61, 271-309.

Johnson, J.P., Lenartowicz, T. (1998). Culture, freedom and economic growth: Do cultural values explain economic growth? Journal of World Business 33, 332-356.

Justesen, M.K. (2008). The effect of economic freedom on growth revisited: New evidence on causality from a panel of countries 1970-1999. European Journal of Political Economy 24, 642660.

Krueger, A.O. (1974). The political economy of the rent-seeking society. American Economic Review 64, 291-303.

Levin, A., Lin, C.-F., Chu, C.-S.J. (2002). Unit root tests in panel data: Asymptotic and finitesample properties. Journal of Econometrics 108, 1-24.

Loyaza, N., Rigolini, J., Llorente, G. (2012). Do middle classes bring about institutional reforms? Economics Letters 116, 440-444.

Marshall, M.G., Gurr, T.R., Jaggers, K. (2014). Polity IV Project: Political Regime Characteristics and Transitions, 1800-2013. Center for Systemic Peace, Vienna, V.A. 
Muller, J.Z. (2013). Capitalism and inequality. Foreign Affairs 92, 30-51.

Nyström, K. (2008). The institutions of economic freedom and entrepreneurship: Evidence from panel data. Public Choice 136, 269-282.

Pitlik, H. (2007). A race to liberalization? Diffusion of economic policy reform among OECDeconomies. Public Choice 132, 159-178.

Pitlik, H., Wirth, S. (2003). Do crises promote the extent of economic liberalization? An empirical test. European Journal of Political Economy 19, 565-581.

Potrafke, N. (2010). Does government ideology influence deregulation of product markets? Empirical evidence from OECD countries. Public Choice 143, 135-155.

Rajan, R.G., Zingales, L. (2003). The great reversals: The politics of financial development in the twentieth century. Journal of Financial Economics 69, 5-50.

Rode, M. Gwartney, J.D. (2012). Does democratization facilitate economic liberalization? European Journal of Political Economy 28, 607-619.

Roine, J., Vlachos, J., Waldenström, D. (2009). The long-run determinants of inequality: What can we learn from top income data? Journal of Public Economics 93, 974-988.

Roodman, D. (2009). How to do xtabond2: An introduction to difference and system GMM in Stata. The Stata Journal 9, 86-136.

Sachs, J.D., Warner, A. (1995). Economic reform and the process of global integration. Brookings Papers on Economic Activity 1, 1-118.

Scully, G.W. (2002). Economic freedom, government policy and the trade-off between equity and economic growth. Public Choice 113, 77-96.

Simmons, B.A., Elkins, Z. (2004). The globalization of liberalization: Policy diffusion in the international political economy. American Political Science Review 98, 171-189.

Solt, F. (2008). Economic inequality and democratic political engagement. American Journal of Political Science 52, 48-60.

Solt, F. (2009). Standardizing the World Income Inequality Database. Social Science Quarterly 90, 231-242.

Sturm, J.-E., De Haan, J. (2015). Income inequality, capitalism, and ethno-linguistic fractionalization. American Economic Review 105, 593-597.

Tullock, G. (1967). The welfare costs of tariffs, monopolies, and theft. Western Economic Journal 5, 224-232. 
Williamson, C.R., Mathers, R.L. (2011). Economic freedom, culture, and growth. Public Choice 148, 313-335.

World Bank (2014). World Development Indicators. The World Bank, Washington, D.C.

Wu, W., Davis, O.A. (1999). The two freedoms, economic growth and development: An empirical study. Public Choice 100, 39-64. 
Figures and Tables

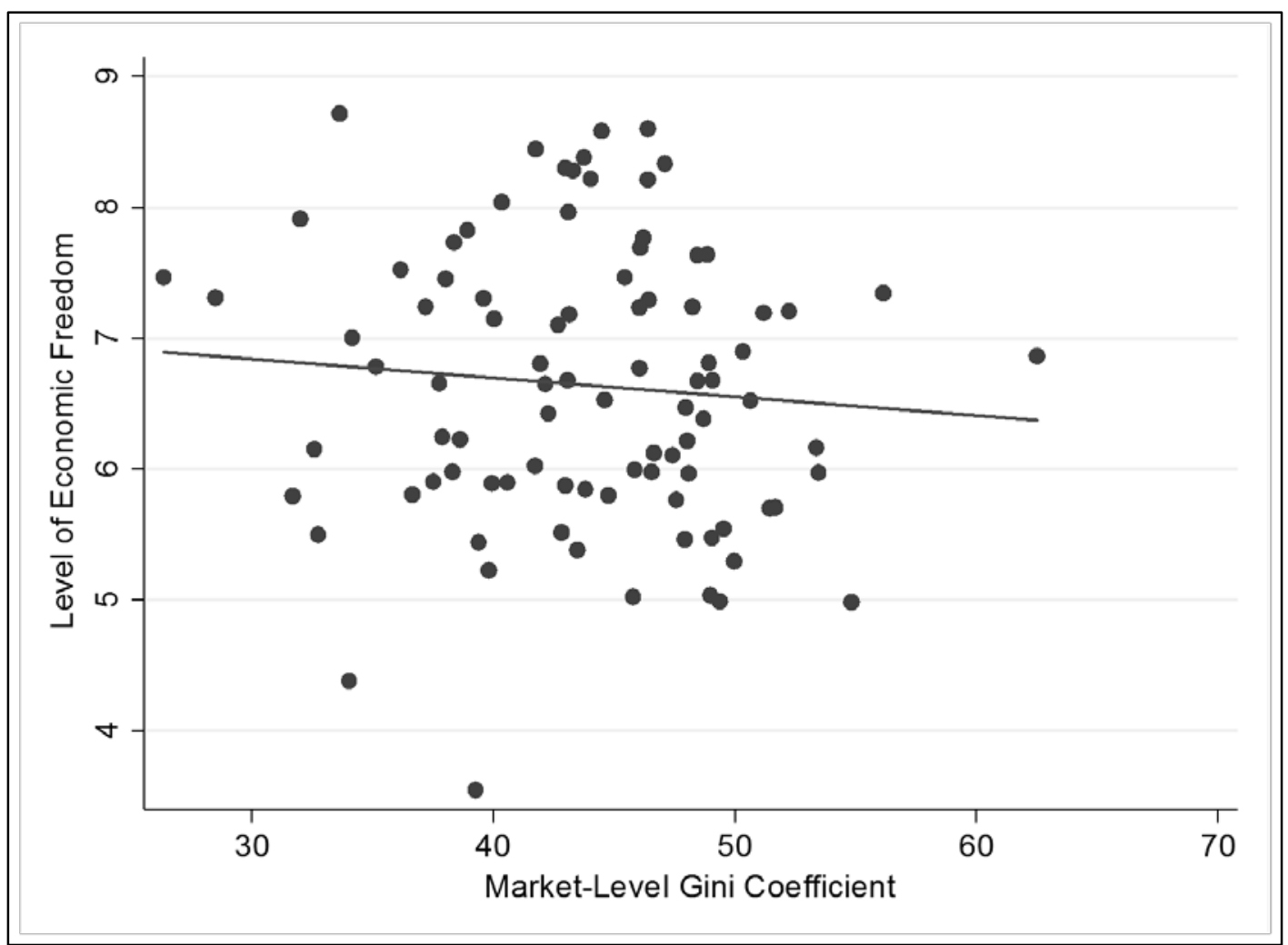

Figure 1: Inequality and Economic Freedom, 2006-2010 


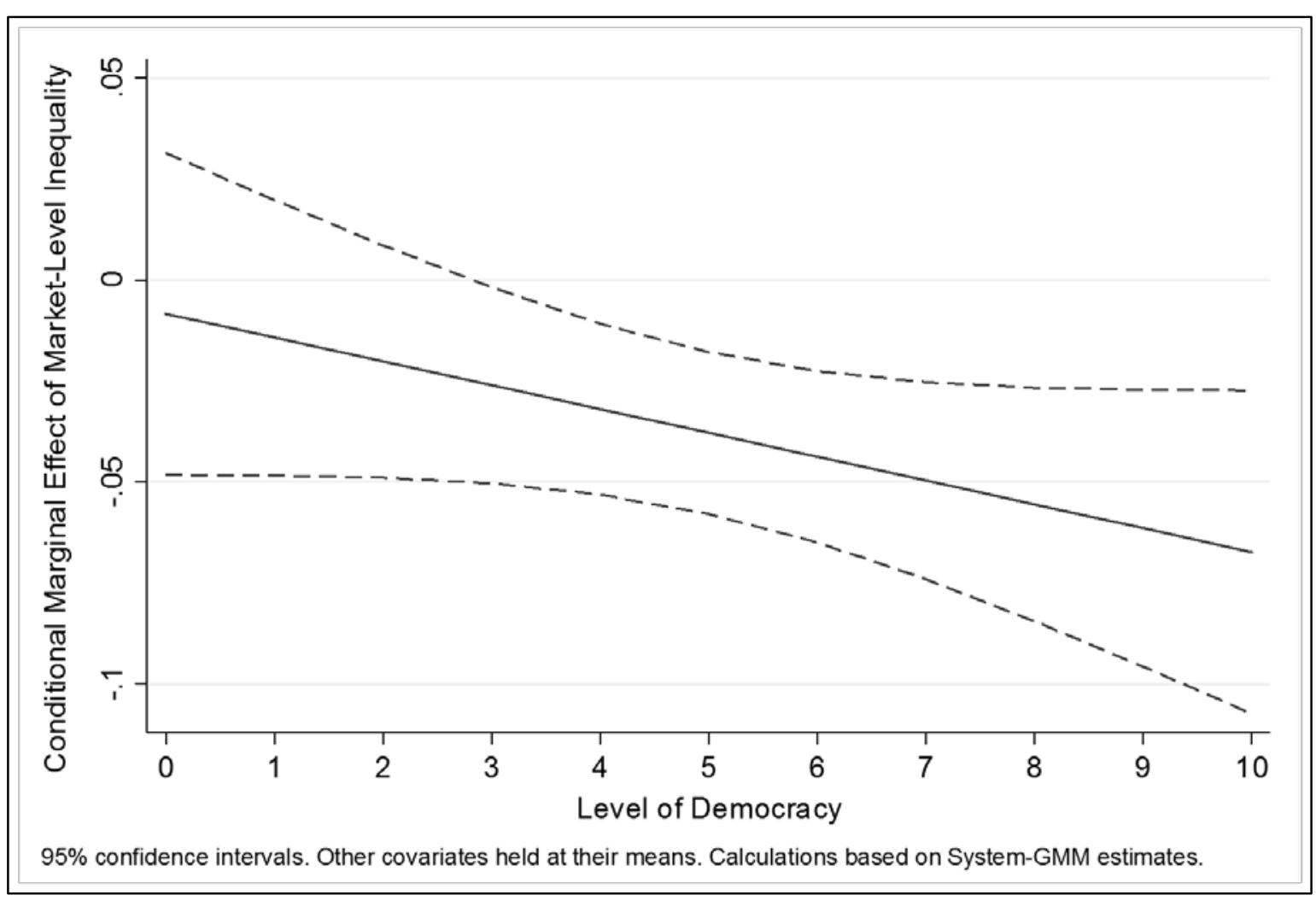

Figure 2: Conditional Marginal Effect of Inequality on the Level of Economic Freedom 


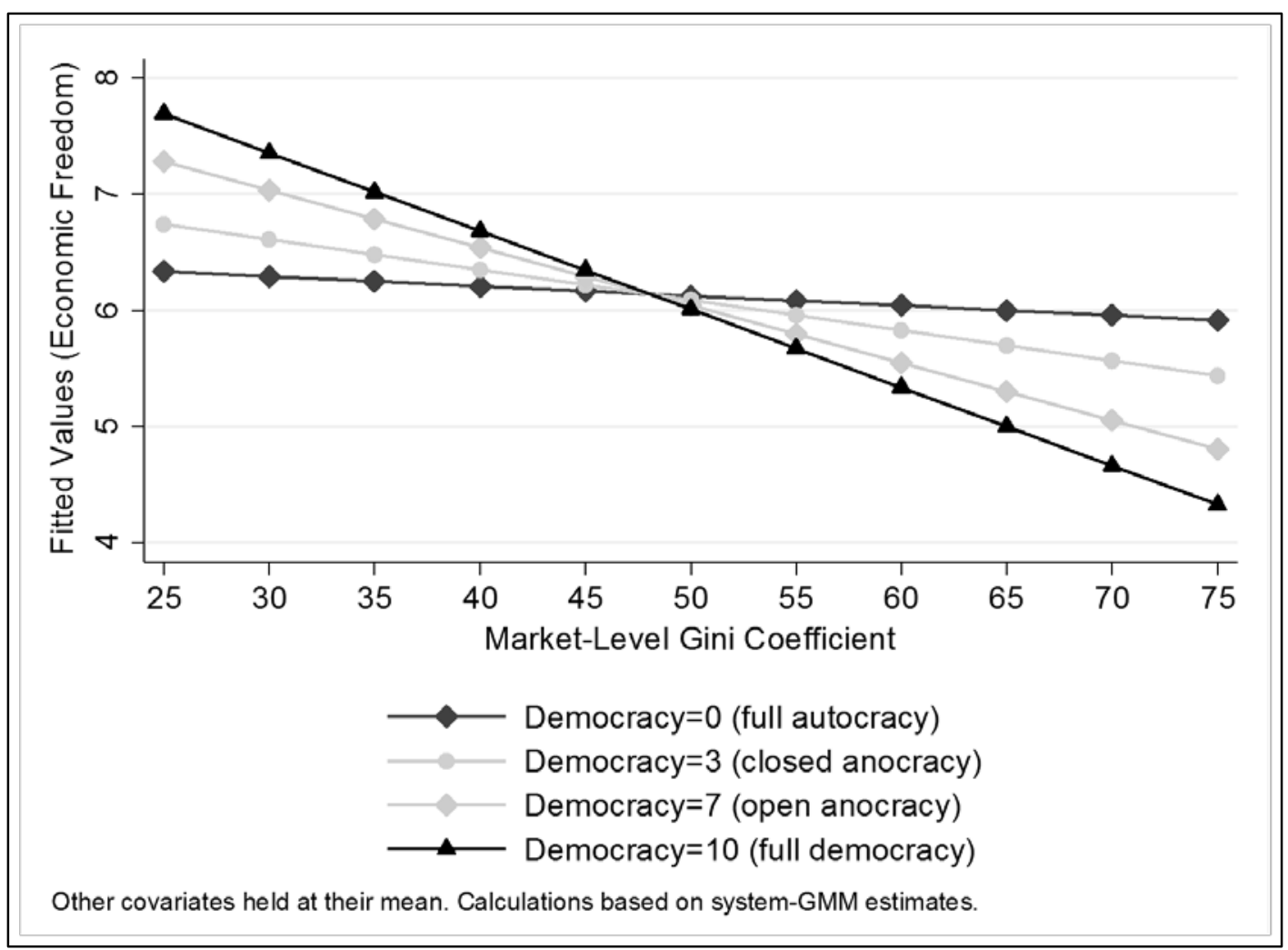

Figure 3: Interaction of Inequality and Democracy and their Effect on Economic Freedom 


\begin{tabular}{llllll}
\hline Variable & $\mathrm{N}^{* T}$ & Mean & $\mathrm{SD}$ & Min. & Max. \\
\hline Economic Freedom & 620 & 6.12 & 1.45 & 2.03 & 9.02 \\
Gini Coefficient & 616 & 44.50 & 8.56 & 21.11 & 75.43 \\
Per Capita Income & 605 & 8.75 & 1.16 & 5.60 & 10.82 \\
Economic Openness & 616 & 53.09 & 20.29 & 6.20 & 99.10 \\
Democracy & 621 & 7.36 & 3.07 & 0.20 & 10 \\
Inflation & 608 & 0.28 & 1.32 & -0.06 & 19.15 \\
Left-Wing Government & 585 & 0.32 & 0.41 & 0 & 1 \\
\hline
\end{tabular}

Table 1: Summary Statistics

\begin{tabular}{llll}
\hline & Exogenous Variables & Economic Freedom & Income Inequality \\
\hline Levin-Lin-Chu Test & Intercept & -21.609 & -141.819 \\
$t$-Statistic & & $(0.00)^{* * *}$ & $(0.00)^{* * *}$ \\
& Intercept and linear trend & -14.202 & -14.636 \\
& & $(0.00)^{* * *}$ & $(0.00)^{* * *}$ \\
Fisher-type PP-Test & Intercept & 450.208 & 367.846 \\
$\chi^{2}$-Statistic & & $(0.00)^{* * *}$ & $(0.00)^{* * *}$ \\
& Intercept and linear trend & 217.727 & 346.763 \\
& & $(0.00)^{* * *}$ & $(0.00)^{* * *}$ \\
\hline
\end{tabular}

Notes: $L L C$-test assumes common unit root process. Fisher-type $P P$-test assumes individual unit root process. Automatic lag length selection via Schwarz Information Criterion. $p$-values in parentheses. $* * *$ $p<0.01$ (indicating the rejection of the null hypothesis of common or individual unit root process).

Table 2: Panel Unit Root Tests 


\begin{tabular}{|c|c|c|c|c|c|c|}
\hline & $\begin{array}{l}F \text {-Test } \\
\text { Statistic }\end{array}$ & $\begin{array}{l}\text { F-Test } \\
\text { Statistic }\end{array}$ & $\chi^{2}$-Statistic & $\chi^{2}$-Statistic & $\chi^{2}$-Statistic & $\chi^{2}$-Statistic \\
\hline Number of Lags & Lags $=1$ & Lags $=2$ & Lags $=1$ & Lags $=2$ & Lags $=1$ & Lags $=2$ \\
\hline Economic Freedom $\nRightarrow$ Income Inequality & $\begin{array}{l}1.38 \\
(0.24)\end{array}$ & $\begin{array}{l}1.15 \\
(0.32)\end{array}$ & $\begin{array}{l}0.99 \\
(0.32)\end{array}$ & $\begin{array}{l}3.44 \\
(0.18)\end{array}$ & $\begin{array}{l}0.70 \\
(0.40)\end{array}$ & $\begin{array}{l}0.48 \\
(0.79)\end{array}$ \\
\hline $\begin{array}{l}\text { Number of Instruments (Number of Countries) } \\
\text { AB Test } \operatorname{AR}(1) / \operatorname{AR}(2) z \text {-statistic } \\
(\operatorname{Pr} .>z) \\
\text { Hansen Test } \chi^{2} \text {-Statistic } \\
\left(\operatorname{Pr} . \chi^{2}\right)\end{array}$ & & & $\begin{array}{l}9(98) \\
-2.35 /-0.36 \\
(0.02) /(0.72) \\
2.39 \\
(0.12)\end{array}$ & $\begin{array}{l}26(91) \\
-2.83 /-0.21 \\
(0.00) /(0.83) \\
16.54 \\
(0.49)\end{array}$ & $\begin{array}{l}14(100) \\
-1.97 /-2.39 \\
(0.04 / 0.02) \\
1.82 \\
(0.87) \\
\end{array}$ & $\begin{array}{l}58(98) \\
-2.86 /-0.47 \\
(0.00) /(0.64) \\
58.11 \\
(0.15)\end{array}$ \\
\hline Income Inequality $\nRightarrow$ Economic Freedom & $\begin{array}{l}11.64 \\
(0.00)^{* * *}\end{array}$ & $\begin{array}{l}8.02 \\
(0.00)^{* * *}\end{array}$ & $\begin{array}{l}10.67 \\
(0.00)^{* * *}\end{array}$ & $\begin{array}{l}4.87 \\
(0.09)^{*}\end{array}$ & $\begin{array}{l}6.90 \\
(0.00) * * *\end{array}$ & $\begin{array}{l}8.78 \\
(0.01)^{* *}\end{array}$ \\
\hline $\begin{array}{l}\text { Number of Instruments (Number of Countries) } \\
\text { AB AR(1)/AR(2) } z \text {-statistic } \\
(\operatorname{Pr} .>z) \\
\text { Hansen Test } \chi^{2} \text {-Statistic } \\
\left(\operatorname{Pr} .>\chi^{2}\right)\end{array}$ & & & $\begin{array}{l}10(99) \\
-3.88 / 0.09 \\
(0.00) /(0.93) \\
1.52 \\
(0.47)\end{array}$ & $\begin{array}{l}35(93) \\
-1.94 /-0.67 \\
(0.05) /(0.51) \\
34.06 \\
(0.13)\end{array}$ & $\begin{array}{l}61(100) \\
-3.80 /-0.03 \\
(0.00) /(0.98) \\
61.92 \\
(0.16)\end{array}$ & $\begin{array}{l}26(99) \\
-3.62 /-0.21 \\
(0.00) /(0.83) \\
19.63 \\
(0.24)\end{array}$ \\
\hline Econometric Method & LSDV & LSDV & Diff-GMM & Diff-GMM & Sys-GMM & Sys-GMM \\
\hline
\end{tabular}

Notes: p-values in parentheses. AB AR(1)/AR(2) =Arrelano-Bond test for first- and second-order serial correlation. Hansen test=Test of instrument over-identification restrictions. Two-step difference-GMM and system-GMM estimates reported. ${ }^{*} p<0.1,{ }^{* *} p<0.05, * * *$ $p<0.01$ (indicating the rejection of the null hypothesis of Granger non-causality).

Table 3: Panel Causality Tests 


\begin{tabular}{|c|c|c|c|c|c|c|}
\hline & (1) & (2) & (3) & (4) & (5) & (6) \\
\hline Income Inequality $t-5$ & $\begin{array}{l}-0.027 \\
(0.014)^{* *}\end{array}$ & $\begin{array}{l}-0.030 \\
(0.011) * * *\end{array}$ & $\begin{array}{l}-0.028 \\
(0.015) *\end{array}$ & $\begin{array}{l}-0.030 \\
(0.012)^{* *}\end{array}$ & $\begin{array}{l}-0.031 \\
(0.012) * * *\end{array}$ & $\begin{array}{l}-0.031 \\
(0.014)^{* *}\end{array}$ \\
\hline Democracy $t-5$ & $\begin{array}{l}0.075 \\
(0.032)^{* *}\end{array}$ & $\begin{array}{l}0.064 \\
(0.023)^{* * *}\end{array}$ & $\begin{array}{l}0.076 \\
(0.037)^{* *}\end{array}$ & $\begin{array}{l}0.060 \\
(0.027)^{* *}\end{array}$ & $\begin{array}{l}0.054 \\
(0.025)^{* *}\end{array}$ & $\begin{array}{l}0.063 \\
(0.032)^{* *}\end{array}$ \\
\hline Per Capita Income $t-5$ & $\begin{array}{l}-0.444 \\
(0.320)\end{array}$ & $\begin{array}{l}-0.480 \\
(0.255)^{*}\end{array}$ & $\begin{array}{l}-0.605 \\
(0.375)\end{array}$ & $\begin{array}{l}0.063 \\
(0.079)\end{array}$ & $\begin{array}{l}0.052 \\
(0.092)\end{array}$ & $\begin{array}{l}0.043 \\
(0.079)\end{array}$ \\
\hline Economic Openness $t-5$ & $\begin{array}{l}0.007 \\
(0.007)\end{array}$ & $\begin{array}{l}0.005 \\
(0.007)\end{array}$ & $\begin{array}{l}0.007 \\
(0.006)\end{array}$ & $\begin{array}{l}0.009 \\
(0.005)^{* *}\end{array}$ & $\begin{array}{l}0.010 \\
(0.005)^{*}\end{array}$ & $\begin{array}{l}0.011 \\
(0.006)^{*}\end{array}$ \\
\hline Inflation $t-5$ & & $\begin{array}{l}0.023 \\
(0.029)\end{array}$ & & & $\begin{array}{l}0.022 \\
(0.034)\end{array}$ & \\
\hline Left-Wing Government $t-5$ & & & $\begin{array}{l}0.122 \\
(0.142)\end{array}$ & & & $\begin{array}{l}0.123 \\
(0.106)\end{array}$ \\
\hline Economic Freedom $t-5$ & $\begin{array}{l}0.403 \\
(0.076) * * *\end{array}$ & $\begin{array}{l}0.376 \\
(0.072)^{* * *}\end{array}$ & $\begin{array}{l}0.419 \\
(0.089) * * *\end{array}$ & $\begin{array}{l}0.618 \\
(0.064)^{* * *}\end{array}$ & $\begin{array}{l}0.630 \\
(0.072) * * *\end{array}$ & $\begin{array}{l}0.620 \\
(0.074) * * *\end{array}$ \\
\hline Econometric Method & Diff-GMM & Diff-GMM & Diff-GMM & Sys-GMM & Sys-GMM & Sys-GMM \\
\hline Number of Instrumen & 87 & 102 & 86 & 52 & 59 & 58 \\
\hline $\begin{array}{l}\operatorname{AB} \operatorname{AR}(1) / A R(2) z \text {-statistic } \\
(\operatorname{Pr} .>z)\end{array}$ & $\begin{array}{l}-3.18 / 0.18 \\
(0.00) /(0.86)\end{array}$ & $\begin{array}{l}-3.06 / 0.19 \\
(0.00) /(0.85)\end{array}$ & $\begin{array}{l}-2.89 / 0.85 \\
(0.00) /(0.39)\end{array}$ & $\begin{array}{l}-3.52 / 0.01 \\
(0.00) /(0.99)\end{array}$ & $\begin{array}{l}-3.41 / 0.02 \\
(0.00) /(0.98)\end{array}$ & $\begin{array}{l}-3.29 / 0.59 \\
(0.00) /(0.55)\end{array}$ \\
\hline Hansen Test $\chi^{2}$-Statistic & 81.80 & 77.74 & 78.78 & 51.19 & 50.47 & 51.84 \\
\hline$\left(\operatorname{Pr} .>\chi^{2}\right)$ & $(0.30)$ & $(0.82)$ & (0.33) & $(0.11)$ & (0.30) & $(0.23)$ \\
\hline $\mathrm{N} * \mathrm{~T}$ & 408 & 396 & 375 & 504 & 492 & 471 \\
\hline
\end{tabular}

Notes: Dependent variable: adjusted economic freedom index. AB AR(1)/AR(2)=Arrelano-Bond test for first- and second-order serial correlation. Hansen test=Test of instrument over-identification restrictions. All specifications include time dummies. Constant not reported. Robust (for system-GMM, Windmeijer-corrected) standard errors in parentheses. Two-step difference-GMM and system-GMM estimates reported. ${ }^{*} p<0.1,{ }^{* *} p<0.05$, ${ }^{* * *} p<0.01$

Table 4: Inequality and Economic Freedom 


\begin{tabular}{|c|c|c|}
\hline & (1) & (2) \\
\hline Income Inequality $t-5$ & $\begin{array}{l}-0.008 \\
(0.020)\end{array}$ & $\begin{array}{l}-0.009 \\
(0.020)\end{array}$ \\
\hline Democracy $t-5$ & $\begin{array}{l}0.302 \\
(0.162)^{*}\end{array}$ & $\begin{array}{l}0.283 \\
(0.173) *\end{array}$ \\
\hline Income Inequality $t-5 *$ Democracy $t-5$ & $\begin{array}{l}-0.005 \\
(0.003)\end{array}$ & $\begin{array}{l}-0.006 \\
(0.004)^{*}\end{array}$ \\
\hline Per Capita Income $t-5$ & $\begin{array}{l}-0.384 \\
(0.359)\end{array}$ & $\begin{array}{l}0.073 \\
(0.129)\end{array}$ \\
\hline Economic Openness $t-5$ & $\begin{array}{l}0.010 \\
(0.008)\end{array}$ & $\begin{array}{l}0.012 \\
(0.006)\end{array}$ \\
\hline Economic Freedom $t-5$ & $\begin{array}{l}0.27 \\
(0.074) * * *\end{array}$ & $\begin{array}{l}0.582 \\
(0.104) * * *\end{array}$ \\
\hline Econometric Method & Diff-GMM & Sys-GMM \\
\hline $\begin{array}{l}\text { Joint Significance Test } \chi^{2} \text {-Statistic } \\
\left(\operatorname{Pr} .>\chi^{2}\right)\end{array}$ & $\begin{array}{l}7.97 \\
(0.04)^{* *}\end{array}$ & $\begin{array}{l}19.60 \\
(0.00)^{* * *}\end{array}$ \\
\hline Number of Instruments & 87 & 58 \\
\hline $\begin{array}{l}\text { AB AR(1)/AR(2) z-statistic } \\
(\operatorname{Pr} .>z)\end{array}$ & $\begin{array}{l}-2.97 /-0.09 \\
(0.00) /(0.93)\end{array}$ & $\begin{array}{l}-315 /-0.16 \\
(0.00) /(0.87)\end{array}$ \\
\hline Hansen Test $\chi^{2}$-Statistic & 77.20 & 56.78 \\
\hline$\left(\operatorname{Pr} .>\chi^{2}\right)$ & $(0.41)$ & $(0.11)$ \\
\hline $\mathrm{N} * \mathrm{~T}$ & 408 & 504 \\
\hline \multicolumn{3}{|c|}{$\begin{array}{l}\text { Notes: Dependent variable: adjusted economic freedom index. All } \\
\text { specifications include time dummies. Constant not reported. AB } \\
\text { AR(1)/AR(2)=Arrelano-Bond test for first- and second-order serial } \\
\text { correlation. Hansen test=Test of instrument over-identification restrictions. } \\
\text { Joint Significance Test=Test on joint significance of the income inequality } \\
\text { and democracy variables and their interaction term. Robust (for system- } \\
\text { GMM, Windmeijer-corrected) standard errors in parentheses. Two-step } \\
\text { difference-GMM and system-GMM estimates reported. }{ }^{*} p<0.1 \text {, }{ }^{* *} p<0.05 \text {, } \\
* * * p<0.01 \text {. }\end{array}$} \\
\hline
\end{tabular}

Table 5: Inequality, Democracy and Economic Freedom 
Appendix A. Country List

\begin{tabular}{|c|c|c|c|}
\hline Albania & El Salvador & Mali & South Africa \\
\hline Algeria & Estonia & Mauritius & South Korea \\
\hline Argentina & Fiji & Mexico & Spain \\
\hline Australia & Finland & Morocco & Sri Lanka \\
\hline Austria & France & Namibia & Sweden \\
\hline Bangladesh & Germany & Nepal & Switzerland \\
\hline Belgium & Ghana & Netherlands & Tanzania \\
\hline Bolivia & Greece & New Zealand & Thailand \\
\hline Botswana & Guatemala & Nicaragua & Trinidad and Tobago \\
\hline Brazil & Guinea-Bissau & Niger & Tunisia \\
\hline Bulgaria & Haiti & Nigeria & Turkey \\
\hline Burundi & Honduras & Norway & Uganda \\
\hline Cameroon & Hungary & Pakistan & Ukraine \\
\hline Canada & India & Panama & United Kingdom \\
\hline Central African Republic & Indonesia & Papua New Guinea & United States \\
\hline Chile & Iran & Paraguay & Uruguay \\
\hline China & Ireland & Peru & Venezuela \\
\hline Colombia & Israel & Philippines & Zambia \\
\hline Costa Rica & Italy & Poland & \\
\hline Cote d'Ivoire & Jamaica & Portugal & \\
\hline Croatia & Japan & Romania & \\
\hline Cyprus & Jordan & Russia & \\
\hline Czech Republic & Kenya & Senegal & \\
\hline Denmark & Latvia & Sierra Leone & \\
\hline Dominican Republic & Madagascar & Singapore & \\
\hline Ecuador & Malawi & Slovak Republic & \\
\hline Egypt & Malaysia & Slovenia & \\
\hline
\end{tabular}


Appendix B. Additional Estimates

\begin{tabular}{llll}
\hline & \multicolumn{1}{c}{$(1)$} & \multicolumn{1}{c}{$(2)$} & \multicolumn{1}{c}{$(3)$} \\
\hline Income Inequality $t-5$ & -0.012 & -0.013 & -0.014 \\
& $(0.07)^{*}$ & $(0.007)^{*}$ & $(0.008)^{*}$ \\
Democracy $t-5$ & 0.088 & 0.080 & 0.097 \\
& $(0.021)^{* * *}$ & $(0.023)^{* * *}$ & $(0.024)^{* * * *}$ \\
Per Capita Income $t-5$ & -0.200 & -0.181 & -0.202 \\
& $(0.172)$ & $(0.179)$ & $(0.200)$ \\
Economic Openness $t-5$ & 0.002 & 0.002 & 0.002 \\
& $(0.004)$ & $(0.005)$ & $(0.005)$ \\
Inflation $t-5$ & & 0.016 & \\
& & $(0.015)$ & \\
Left-Wing Government $t-5$ & & & 0.062 \\
& & & $(0.060)$ \\
\hline Econometric Method & LSDV & LSDV & LSDV \\
Within $R^{2}$ & 0.609 & 0.596 & 0.581 \\
$\mathrm{~N}^{*} \mathrm{~T}$ & 504 & 492 & 471 \\
\hline Notes: Dependent variable: adjusted economic freedom index. All
\end{tabular}

Notes: Dependent variable: adjusted economic freedom index. All

specifications include time dummies. Constant not reported. Robust

standard errors in parentheses. ${ }^{*} p<0.1,{ }^{* *} p<0.05, * * * p<0.01$.

Supplementary Table 1: Inequality and Economic Freedom (Static LSDV Estimates) 


\begin{tabular}{|c|c|c|c|}
\hline & (1) & $(2)$ & (3) \\
\hline Income Inequality $t-5$ & $\begin{array}{l}-0.012 \\
(0.005)^{* *}\end{array}$ & $\begin{array}{l}-0.012 \\
(0.005) * *\end{array}$ & $\begin{array}{l}-0.010 \\
(0.005)^{* *}\end{array}$ \\
\hline Democracy $t-5$ & $\begin{array}{l}0.060 \\
(0.167)^{* * *}\end{array}$ & $\begin{array}{l}0.056 \\
(0.017)^{* * *}\end{array}$ & $\begin{array}{l}0.066 \\
(0.017) * * *\end{array}$ \\
\hline Per Capita Income $t-5$ & $\begin{array}{l}-0.244 \\
(0.123)^{* *}\end{array}$ & $\begin{array}{l}-0.227 \\
(0.127)^{*}\end{array}$ & $\begin{array}{l}-0.261 \\
(0.129)^{* *}\end{array}$ \\
\hline Economic Openness $t-5$ & $\begin{array}{l}0.001 \\
(0.003)\end{array}$ & $\begin{array}{l}0.001 \\
(0.003)\end{array}$ & $\begin{array}{l}0.001 \\
(0.003)\end{array}$ \\
\hline Inflation $t-5$ & & $\begin{array}{l}0.032 \\
(0.017) *\end{array}$ & \\
\hline Left-Wing Government $t-5$ & & & $\begin{array}{l}0.085 \\
(0.052\end{array}$ \\
\hline Economic Freedom $t-5$ & $\begin{array}{l}0.375 \\
(0.052)^{* * *}\end{array}$ & $\begin{array}{l}0.377 \\
(0.056)^{* * *}\end{array}$ & $\begin{array}{l}0.417 \\
(0.042) * * *\end{array}$ \\
\hline Econometric Method & LSDV & LSDV & LSDV \\
\hline Within $R^{2}$ & 0.684 & 0.673 & 0.671 \\
\hline $\mathrm{N} * \mathrm{~T}$ & 504 & 492 & 471 \\
\hline $\begin{array}{l}\text { Notes: Dependent variable } \\
\text { specifications include time } \\
\text { standard errors in parenthe }\end{array}$ & $\begin{array}{l}\text { adjusted e } \\
\text { dummies. C } \\
\text { es. }{ }^{*} p<0.1 \text {, }\end{array}$ & $\begin{array}{l}\text { nomic freedo } \\
\text { istant not rep } \\
{ }^{*} p<0.05, * * * \\
\end{array}$ & $\begin{array}{l}m \text { index. All } \\
\text { orted. Robust } \\
p<0.01 \text {. }\end{array}$ \\
\hline
\end{tabular}

